\title{
Urinary continence and erectile dysfunction results in robot-assisted radical prostatectomy with endopelvic fascia preservation
}

\section{Resultados de continencia urinaria y disfunción eréctil en la prostatectomía radical robótica con preservación de la fascia endopélvica.}

\author{
Saskia Mercedes Suarez Salgado, ${ }^{1^{*}}$ D María Fernanda Rosero Morillo. ${ }^{1}$
}

Key words:

robot-assisted

prostatectomy; functional results;

prostate

Corresponding author:

*Saskia Mercedes Suarez

Salgado. Hospital de

Especialidades Carlos

Andrade Marín,

Av. Universitaria, Quito 170103, Ecuador. Email: saskiasuarezs@hotmail.

com

\section{Abstract}

Introduction: Radical prostatectomy is the treatment of choice for patients with organ-confined prostate cancer due to its oncological benefits and survival. With the advancement of technology, surgical techniques have been modified, and robot-assisted radical prostatectomy (RARP) is currently the procedure with the most advanced technology. Due to its multiple advantages, such as short-term functional and surgical results, shorter hospital stay and minimal invasiveness, it constitutes a valid therapeutic option to consider for this group of cancer patients.

Objective: To compare the results obtained in urinary continence and erectile dysfunction after RARP with a standard da Vinci ${ }^{\circledR}$ system with 4 arms, between a group of 43 patients who underwent said procedure, without preservation of the endopelvic fascia in 2018, and 68 patients who underwent the same procedure with endopelvic fascia preservation, between January 2019 and February 2021, all at the Hospital Carlos Andrade Marín, in Quito.

Methodology: A retrospective longitudinal descriptive observational study was made, with the comparison of 68 prostate cancer patients who underwent radical surgery with endopelvic fascia preservation at the Hospital Carlos Andrade Marín, between January 2019 and February 2021, and 43 patients who had the same surgery but without endopelvic preservation, in the year 2019.

Results: One hundred eleven surgeries for prostate cancer with the robot-assisted radical prostatectomy technique were performed. Forty-three (37.8\%) surgeries were made without endopelvic fascia preservation, and $68(61.3 \%)$ were made with endopelvic fascia preservation. At the first month of follow-up, 25 (58\%) patients of the RARP without endopelvic fascia preservation group, presented with severe erectile dysfunction, 11 (26\%) with moderate erectile dysfunction, $6(14 \%)$ with moderate to mild erectile dysfunction, and $1(2 \%)$ with mild erectile dysfunction. At 6 months follow-up, of the 25 patients with severe dysfunction, 2 presented with moderate dysfunction and 23 remained with severe dysfunction. Of the patients who underwent RARP with endopelvic fascia preservation, 54 (80\%) presented with mild incontinence, and 3 (4\%) were completely continent making use of this technique. Furthermore, at 9 months follow-up, $90 \%$ of the patients had complete continence and $10 \%$ mild incontinence. Fifty six percent of the RARP patients with endopelvic fascia preservation presented severe sexual dysfunction at the first postoperative month. However, after pharmacological treatments, only $19 \%$ remained with erectile dysfunction. Conclusion: RARP is a safe and minimally invasive technique, it improves surgical and functional results, in the short and long terms, with respect to continence and sexual function. Endopelvic fascia preservation could improve results in the long term for continence and erectile dysfunction.

Citation: Suárez-Salgado S. M., Rosero-Morillo M. F. Resultados de continencia urinaria y disfunción eréctil en la prostatectomía radical robótica con preservación de la fascia endopélvica. Rev Mex Urol. 2021;81(6):pp. 1-9

${ }^{1}$ Hospital de Especialidades Carlos Andrade Marín, Quito-Ecuador.

Received: October 10, 2021

Accepted: November 10, 2021

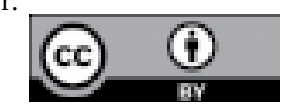




\section{Urinary continence and erectile dysfunction results in robot-assisted... Suarez Salgado S. M., et al.}

Palabras clave: prostatectomía robótica, resultados funcionales, próstata
Resumen

Introducción: La prostatectomía radical es el tratamiento de elección para los pacientes con cáncer de próstata, debido a sus beneficios oncológicos y sobrevida. Conforme ha avanzado la tecnología, la medicina ha incursionado en las técnicas quirúrgicas han sido modificadas, siendo actualmente la prostatectomía radical asistida por robot el procedimiento con la tecnología más avanzada actualmente. Debido a sus múltiples ventajas como resultados funcionales y quirúrgicos a corto plazo, menor tiempo hospitalario y mínimamente invasivo constituye una opción terapéutica válida para tener en cuenta en el tratamiento de pacientes con este padecimiento oncológico.

Objetivo: Comparar los resultados obtenidos de continencia urinaria y disfunción eréctil posterior a prostatectomía radical asistida por robot da Vinci Standard de 4 brazos realizadas en Quito en el Hospital Carlos Andrade Marín realizadas sin preservación de la fascia endopélvica en el año 2018 (43) frente a pacientes sometidos a la misma cirugía con preservación de la fascia endopélvica (68) entre enero del 2019 a febrero 2021.

Metodología: Se realizó un estudio observacional descriptivo de corte longitudinal retrospectivo en 68 pacientes con cáncer de próstata sometidos a cirugía radical con preservación de la fascia endopélvica en el Hospital Carlos Andrade Marín desde enero del 2019 a febrero 2021 en Quito, Ecuador y se comparó con 43 pacientes sometidos a la misma cirugía con la característica de no preservar la fascia endopélvica en el año 2019. Resultados: Se realizaron 111 cirugías por cáncer de próstata localizado utilizando la técnica robótica para prostatectomía radical, $43(38,7 \%)$ cirugías se realizaron sin preservación de la fascia endopélvica, y $68(61,3 \%)$ se realizaron con preservación de fascia endopélvica.

En la prostatectomía radical asistida por robot sin preservación de fascia endopélvica, al primer mes de seguimiento, 25 (58\%) tuvieron disfunción sexual grave, $11(26 \%)$ moderada, $6(14 \%)$ leve a moderada y $1(2 \%)$ paciente con disfunción sexual leve, a los 6 meses de los 25 pacientes con disfunción grave, 2 pacientes presentaban disfunción eréctil moderada, y 23 disfunción grave. Los pacientes sometidos a prostatectomía radical asistida por robot con preservación de la fascia endopélvica, mostraron una incontinencia leve $80 \%$ (54) y $4 \%$ (3) que estuvieron totalmente continentes usando esta técnica. Además, a los 9 meses el $90 \%$ de los pacientes tenían una continencia total y $10 \%$ tenían incontinencia leve. La disfunción sexual posoperatoria en pacientes con PRR con preservación de fascia endopélvica, al primer mes posoperatorio el $56 \%$ de pacientes tenían una disfunción eréctil severa sin embargo posterior a tratamientos farmacológicos apenas el $19 \%$ se quedó con disfunción eréctil.

Conclusión: La prostatectomía radical asistida por robot es una de las técnicas mínimamente invasivas y seguras para los pacientes, que logran mejorar los resultados quirúrgicos y funcionales tanto de continencia y función sexual de los pacientes a corto y largo plazo, la preservación de la fascia endopélvica podría mejorar los resultados a largo plazo de continencia y disfunción eréctil.

\section{Introduction}

Cancer is a global health problem and its incidence and mortality rates vary between countries. Prostate neoplasia can stay asymptomatic for several years, and its natural history is not completely clear. Its most frequent symptoms are not exclusive to it, and when they are apparent, the disease may have spread out from the prostate. ${ }^{(1)}$ About 1 in 9 men will be diagnosed with prostate cancer during their lifetime, and it is more frequent in older men and in black men. Approximately, 6 out of 10 cases are diagnosed in men of 65 years of age or more, and it appears before 40 years of age on few occasions. The average age of onset is $66 .^{(2)}$

Cancer is the second cause of death worldwide. In 2015 , there were 17.5 million cases of 
cancer. Prostate cancer was the most common type in men (1.6 million cases). ${ }^{(3)}$ The incidence of prostate cancer in Ecuador is in a medium-high range, with $18.3 \%$ in $2017 .^{(4)}$ Radical prostatectomy is the treatment of choice for patients with organ-confined prostate cancer, with various techniques available, such as open surgery, laparoscopy, and robot-assisted, each having advantages and disadvantages. ${ }^{(5)}$

The laparoscopic and robot-assisted techniques are minimally invasive, and they have shown better surgical results, in comparison with the open surgery technique. However, the robot-assisted technique has proven to be superior to the laparoscopy, except for the duration of the procedure. ${ }^{(6)}$ Two important functional results to determine the impact in quality of life include continence and sexual function. Compared with the open surgery technique, the robot-assisted technique has statistically significant advantages. Finally, oncologic results of the robot-assisted radical prostatectomy (RARP) have been the same as with other techniques, regarding relapse or residual disease. ${ }^{(7)}$

The indications for laparoscopic radical prostatectomy are localized prostate adenocarcinoma (T1-T2), without metastasis, and locally advanced (T3) without metastasis, both in patients with life expectancy of more than 10 years. Patients need to be informed that it may be necessary to complement the treatment with radiotherapy. ${ }^{(8)}$ In order to perform laparoscopic radical prostatectomy, it is convenient that the patient hasn't undergone any previous abdominal surgery, hence the indication of this technique for patients between 70 and 75 years of age. ${ }^{(9)}$ RARP is a better technique when comparing functional, oncologic and perioperative results with conventional therapy in localized prostate cancer. ${ }^{(10)}$ Robotic surgery is a (minimally invasive) laparoscopic procedure, in which the surgeon operates a set of four robotic arms (three of which hold surgical instruments and the fourth holds a 3D camera). This robotic system is known as da Vinci, and from the surgeons' perspective, it has advantages over other techniques, such as image enlargement, articulated instrumentation, better ergonomics, filtering of tremors, wider range of movements, and a shorter learning curve, compared to laparoscopy. ${ }^{(11)}$

This leads to an improved surgeon precision when extracting the prostate, and to a decrease of the likelihood of leaving positive (oncologic) margins, as well as to a reduction of surgical times, and functional and perioperative complications. ${ }^{(12)}$

Regarding sexual dysfunction, a randomized controlled trial (RCT) ${ }^{(13)}$ showed that there was an improvement in the recovery rate of erectile function ( $63 \%$ vs $13 \%$, $\mathrm{p}<0.01$ ), 3 months after surgery with RARP, in comparison with laparoscopic surgery. Another RCT, ${ }^{(14)} \mathrm{did}$ not find significant differences ( $40 \%$ vs $60 \%$, $\mathrm{p}=0.09$ ). At 6 months postoperative, according to the same study,(14) RARP was better than laparoscopic surgery to improve the erectile function recovery rate ( $75 \%$ vs $22 \%, \mathrm{p}<0.01)$, but another RCT did not find evidence for said differences ( $48.5 \%$ vs $65.7 \%$, $\mathrm{p}=0.14$, for laparoscopy and RARP, respectively). ${ }^{(15)}$

At 3 months postoperative, an RCT couldn't find evidence for urinary continence recovery significant differences, ${ }^{(16)}$ when comparing RARP to laparoscopy (69\% vs $63 \%$, respectively, $\mathrm{p}=0.51$ ), on the other hand, another RCT did show significant differences in favor of RARP ( $80 \%$ vs $61.6 \%, p=0.044){ }^{(17)}$ 


\section{Urinary continence and erectile dysfunction results in robot-assisted... Suarez Salgado S. M., et al.}

An RCT, ${ }^{(18)}$ showed that at 6 months, RARP was not different than laparoscopic surgery to recover urinary continence ( $75 \%$ vs $88 \%, \mathrm{p}=0.06$ ). The meta-analysis of these two RCTs found an advantage for RARP (RR: 1.14; CI 95\%: 1.04-1.24). ${ }^{(19)}$

As the understanding of the anatomy of the male pelvis has advanced, the technique for the preservation of the endopelvic fascia has been developed, with excellent results. Several case series have shown free surgical margins (13\%), 50\% of the patients with preserved sexual function at 1 month postoperative, and $86 \%$ after 1 year. Also, $85.9 \%$ had immediate continence, and 98.4 after 1 year. ${ }^{(20)}$

Another study showed that the preservation of the endopelvic fascia improved continence and erectile function results at 12 months in a $95.6 \%$ and $75 \%$, respectively. ${ }^{(20)}$

For all these reasons, a retrospective longitudinal descriptive observational study was made, to evaluate functional results in 111 patients who underwent RARP, comparing the procedure with preservation of endopelvic fascia, and without it.

\section{Objective}

To evaluate and compare results for sexual dysfunction and urinary continence after RARP with standard 4 arm da Vinci robot, performed at the Hospital Carlos Andrade Marín, with a cohort of 111 patients with prostate cancer diagnosis, operated in the city of Quito, between 2019 and 2021, where 43 patients were operated without endopelvic fascia preservation, and 68 with preservation.

\section{Materials and methods}

A descriptive retrospective study was designed for 111 patients with prostate cancer, who underwent radical surgery at the same hospital, the Carlos Andrade Marin, in the city of Quito, in the period between 2019 and 2021. The data was obtained from the clinical records of the information system AS 400, and from continence and sexual dysfunction questionnaires, pre- and post-surgery, from each patient.

\section{Results}

One hundred eleven surgeries for localized prostate cancer were performed, using the RARP technique. In 43 patients (38.7\%) the procedure was made without endopelvic fascia preservation, while in $68(61.3 \%)$, it was made with said fascia preservation.

Fifty eight percent of the patients who underwent the RARP, were between 61 and 70 years of age, and only 3\% under 50 years of age. Figure 1. 
Figure 1. RARP age groups

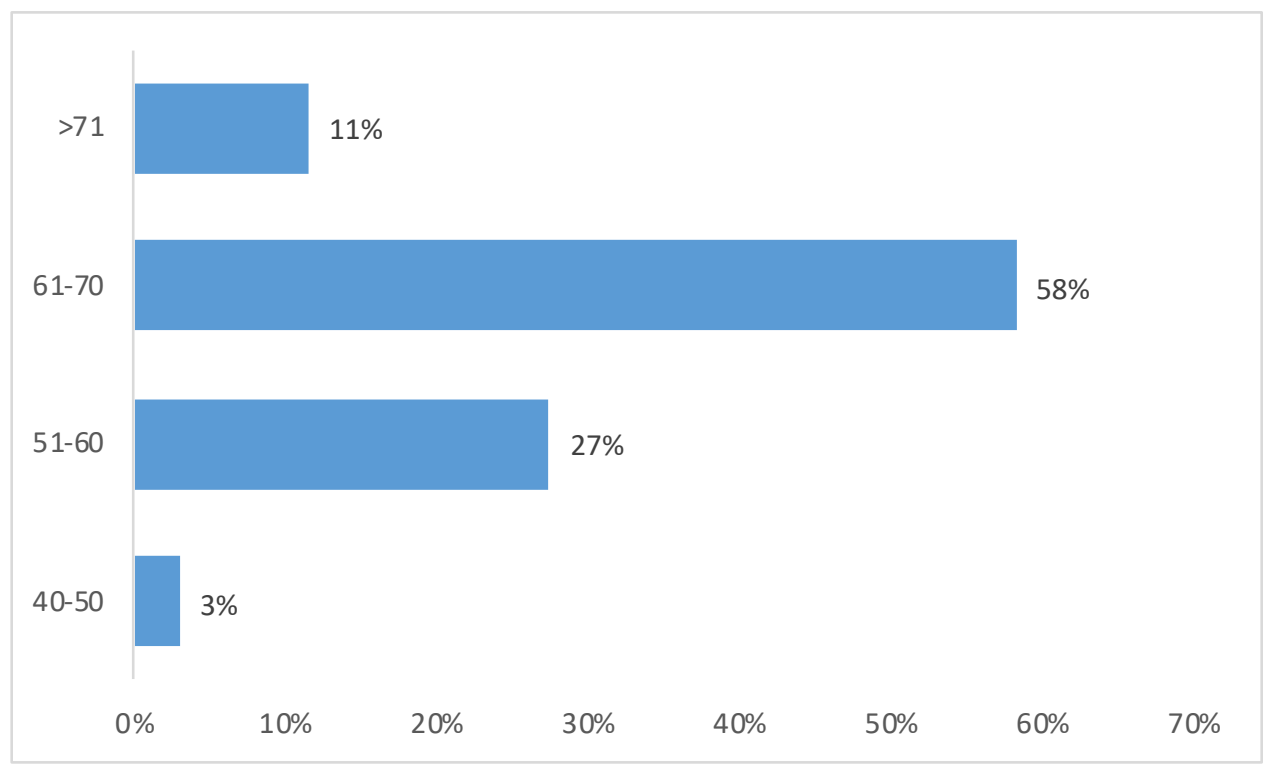

The surgical average time was 3:30 minutes (min 1:30 min, max 6:30) for both groups. Regarding preoperative urinary continence, $100 \%$ (111 patients) had total continence. While for sexual dysfunction, it was found that, according to SHIM, almost $33 \%$ of the patients already had mild to moderate dysfunction, and only $12 \%$ did not have any dysfunction. Figure 2 .

Figure 2. Preoperative sexual dysfunction severity

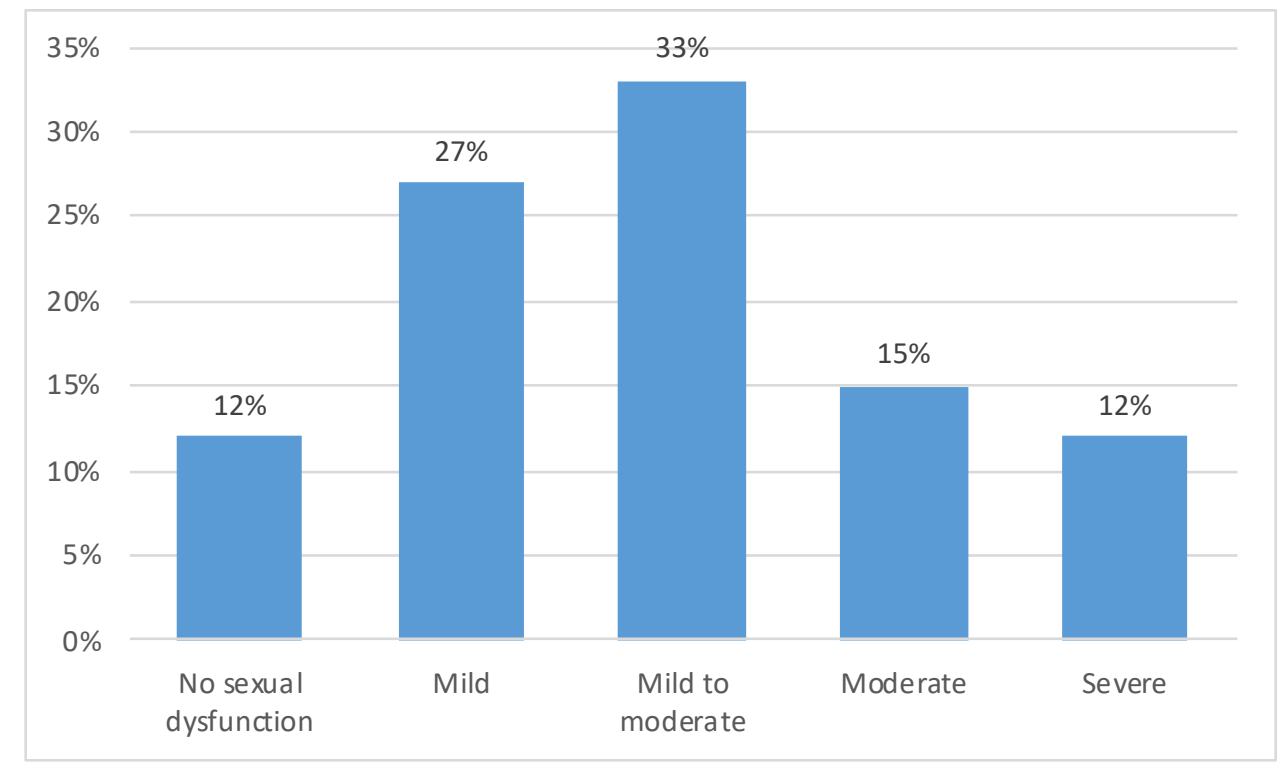


After RARP without endopelvic preservation, at 1 month postoperative, 25 patients (58\%) had severe sexual dysfunction, 11 (26\%) moderate, 6 (14\%) mild to moderate, and 1 (2\%) mild. However, at 6 months postoperative, of the 25 patients with severe dysfunction, 23 remained with the same degree of dysfunction. (Table 1 )

Table 1: Postoperative sexual dysfunction in patients without endopelvic fascia preservation

\begin{tabular}{|c|c|c|c|c|c|c|c|c|c|c|}
\hline & \multicolumn{10}{|c|}{ Erectile dysfunction severity } \\
\hline & No ED & $\%$ & Mild & $\%$ & $\begin{array}{l}\text { Mild to } \\
\text { moderate }\end{array}$ & $\%$ & Moderate & $\%$ & Severe & $\%$ \\
\hline 1 month & 0 & $0 \%$ & 1 & $2 \%$ & 6 & $14 \%$ & 11 & $26 \%$ & 25 & $58 \%$ \\
\hline 3 months & 0 & $0 \%$ & 2 & $5 \%$ & 9 & $21 \%$ & 8 & $19 \%$ & 24 & $56 \%$ \\
\hline 6 months & 0 & $0 \%$ & 2 & $5 \%$ & 9 & $21 \%$ & 9 & $21 \%$ & 23 & $53 \%$ \\
\hline 9 months & 0 & $0 \%$ & 2 & $5 \%$ & 9 & $21 \%$ & 9 & $21 \%$ & 23 & $53 \%$ \\
\hline
\end{tabular}

With respect to urinary continence in patients with endopelvic fascia preservation, it was shown that, after 1 month, 34 patients (79\%) had mild incontinence, which improved at 6 months. At 9 months postoperative, there were no patients with severe incontinence. Although some patients required pelvic floor physiotherapy, good results were obtained to improve quality of life. Ninety eight percent (42) of the patients recovered continence after surgery at 9 months. (Table 2)

Table 2: Postoperative continence in patients without endopelvic fascia preservation

\begin{tabular}{lcccccccc}
\hline & \multicolumn{7}{l}{ Continence } & \multicolumn{7}{c}{ Incontinence } \\
& $N^{0}$ & $\%$ & Mild & $\%$ & Moderate & $\%$ & Severe & $\%$ \\
\hline 1 month & 1 & $2 \%$ & 34 & $79 \%$ & 8 & $19 \%$ & 0 & $0 \%$ \\
\hline 3 months & 35 & $81 \%$ & 7 & $16 \%$ & 1 & $2 \%$ & 0 & $0 \%$ \\
\hline 6 months & 38 & $88 \%$ & 5 & $12 \%$ & 0 & $0 \%$ & 0 & $0 \%$ \\
\hline 9 months & 42 & $98 \%$ & 1 & $2 \%$ & 0 & $0 \%$ & 0 & $0 \%$ \\
\hline
\end{tabular}

The results for urinary continence in patients who underwent RARP with endopelvic fascia preservation showed that the percentage was higher in patients with mild incontinence $(80 \%)$, while $4 \%$ (3 patients) had complete continence after using said technique, as shown in Table 3 . At 9 months postoperative, $90 \%$ of the patients had total continence, and $10 \%$ had mild incontinence, which however, did not affect their lifestyle. Tabla 3 
Table 3: Postoperative continence in patients with endopelvic fascia preservation

\begin{tabular}{lcccccccc}
\hline & \multicolumn{7}{c}{ Continence } & \multicolumn{5}{c}{ Incontinence } \\
\cline { 2 - 10 } & $N^{0}$ & $\%$ & Mild & $\%$ & Moderate & $\%$ & Severe & $\%$ \\
\hline 1 month & 3 & $4 \%$ & 54 & $80 \%$ & 11 & $16 \%$ & 0 & $0 \%$ \\
\hline 3 months & 52 & $75 \%$ & 15 & $24 \%$ & 1 & $1 \%$ & 0 & $0 \%$ \\
\hline 6 months & 59 & $87 \%$ & 8 & $12 \%$ & 1 & $1 \%$ & 0 & $0 \%$ \\
\hline 9 months & 61 & $90 \%$ & 7 & $10 \%$ & 0 & $0 \%$ & 0 & $0 \%$ \\
\hline
\end{tabular}

Regarding sexual dysfunction in patients who underwent RARP with endopelvic fascia preservation, the results showed that at 1 month postoperative, $56 \%$ of the patients had severe erectile dysfunction. However, after pharmacologic treatment, at 9 months postoperative, only $19 \%$ remained with severe erectile dysfunction. Being refractory to the clinical treatment, they were offered alternatives, such as injections or prosthetics. Most patients who underwent RARP with endopelvic fascia preservation had moderate erectile dysfunction at 9 months postoperative. Table 4

Table 4: Postoperative sexual dysfunction in patients with endopelvic fascia preservation

\begin{tabular}{lcccccccccc}
\hline & No ED & $\%$ & Mild & $\%$ & $\begin{array}{c}\text { Mild to } \\
\text { moderate }\end{array}$ & $\%$ & Moderate & $\%$ & Severe & $\%$ \\
\hline 1 month & 0 & $0 \%$ & 2 & $3 \%$ & 8 & $12 \%$ & 20 & $29 \%$ & 38 & $56 \%$ \\
\hline 3 months & 0 & $0 \%$ & 1 & $1 \%$ & 10 & $15 \%$ & 36 & $53 \%$ & 21 & $31 \%$ \\
\hline 6 months & 0 & $0 \%$ & 1 & $1 \%$ & 11 & $16 \%$ & 39 & $57 \%$ & 17 & $25 \%$ \\
\hline 9 months & 0 & $0 \%$ & 1 & $1 \%$ & 13 & $19 \%$ & 41 & $60 \%$ & 13 & $19 \%$ \\
\hline
\end{tabular}

\section{Conclusions}

It was shown that, for urinary continence, at 1 month follow-up, there was mild incontinence in $79 \%$ of the patients in the RARP without endopelvic fascia preservation group, and in $80 \%$ of the patients in the RARP with endopelvic fascia preservation. At the end of the 9 months follow-up, $98 \%$ of the patients in the group without fascia preservation had total continence, while for the group with fascia preservation it was $90 \%$.
The results for sexual dysfunction showed a difference between the two techniques, where $58 \%$ of the patients had severe erectile dysfunction that did not improve with time in the group without endopelvic fascia preservation, as $56 \%$ of them remained with severe erectile dysfunction at 9 months postoperative. For patients with endopelvic fascia preservation, it was shown that at 1 month postoperative, $56 \%$ had severe erectile dysfunction, but the percentage decreased to $19 \%$ at 9 months postoperative. 


\section{Urinary continence and erectile dysfunction results in robot-assisted... Suarez Salgado S. M., et al}

This descriptive study can be a tool to evaluate functional results in patients who undergo RARP with or without endopelvic fascia preservation, to contribute to statistical analyses, and to have better post-surgery complication control. However, more and larger studies, with bigger groups of patients, need to be made, for these results to become a recommendation.

\section{Funding}

No sponsorship of any kind was received to carry out this article.

\section{Conflict of interest}

The authors declare that they have no conflict of interest.

\section{References}

1. Walsh PC, Lepor H, Eggleston JC. Radical prostatectomy with preservation of sexual function: anatomical and pathological considerations. Prostate. 1983;4(5):473-85. doi: https://doi.org/10.1002/pros.2990040506

2. Schuessler WW, Schulam PG, Clayman RV, Kavoussi LR. Laparoscopic radical prostatectomy: initial short-term experience. Urology. 1997;50(6):854-7. doi: https://doi. org/10.1002/pros.2990040506

3. Davis M, Egan J, Marhamati S, Galfano A, Kowalczyk KJ. Retzius-Sparing Robot-Assisted Robotic Prostatectomy: Past, Present, and Future. Urologic Clinics of North America.
2021 Feb 1;48(1):11-23. doi: https://doi. org/10.1016/j.ucl.2020.09.012

4. Guillonneau B, Cathelineau $\mathbf{X}$, Barret $\mathbf{E}$, Rozet F, Vallancien G. [Laparoscopic radical prostatectomy. Preliminary evaluation after 28 interventions]. Presse Med. 1998;27(31):1570-4.

5. Rassweiler J, Sentker L, Seemann O, Hatzinger M, Stock C, Frede T. Heilbronn laparoscopic radical prostatectomy. Technique and results after 100 cases. Eur Urol. 2001;40(1):54-64. doi: https://doi.org/10.1159/000049749

6. Gregori A, Simonato A, Lissiani A, Bozzola A, Galli S, Gaboardi F. Laparoscopic radical prostatectomy: perioperative complications in an initial and consecutive series of 80 cases. Eur Urol. 2003;44(2):190-4; discussion 194. doi: https://doi.org/10.1016/S03022838(03)00261-6

7. Stolzenburg J-U, Do M, Rabenalt R, Pfeiffer H, Horn L, Truss MC, et al. Endoscopic extraperitoneal radical prostatectomy: initial experience after 70 procedures. J Urol. 2003;169(6):2066-71. doi: https://doi. org/10.1097/01.ju.0000067220.84015.8e

8. Poulakis V, Dillenburg W, Moeckel M, de Vries R, Witzsch U, Zumbé J, et al. Laparoscopic radical prostatectomy: prospective evaluation of the learning curve. European urology. 2005;47(2). doi: https://doi.org/10.1016/j. eururo.2004.09.006

9. El-Feel A, Davis JW, Deger S, Roigas J, Wille AH, Schnorr D, et al. Positive margins after laparoscopic radical prostatectomy: a prospective study of 100 cases performed by 4 different surgeons. Eur Urol. 2003;43(6):6226. doi: https://doi.org/10.1016/S03022838(03)00148-9

10. Raboy A, Ferzli G, Albert P. Initial experience with extraperitoneal endoscopic 
radical retropubic prostatectomy. Urology. 1997;50(6):849-53. doi: https://doi. org/10.1016/S0090-4295(97)00485-8

11. Bollens R, Vanden Bossche M, Roumeguere T, Damoun A, Ekane S, Hoffmann P, et al. Extraperitoneal laparoscopic radical prostatectomy. Results after 50 cases. Eur Urol. 2001;40(1):65-9. doi: https://doi. org/10.1159/000049750

12. Brown JA, Rodin D, Lee B, Dahl DM. Transperitoneal versus extraperitoneal approach to laparoscopic radical prostatectomy: an assessment of 156 cases. Urology. 2005;65(2):320-4. doi: https://doi. org/10.1016/j.urology.2004.09.018

13. Remzi M, Klingler HC, Tinzl MV, Fong YK, Lodde M, Kiss B, et al. Morbidity of laparoscopic extraperitoneal versus transperitoneal radical prostatectomy verus open retropubic radical prostatectomy. Eur Urol. 2005;48(1):83-9; discussion 89. doi: https://doi.org/10.1016/j. eururo.2005.03.026

14. Rassweiler J, Sentker L, Seemann O, Hatzinger M, Rumpelt HJ. Laparoscopic radical prostatectomy with the Heilbronn technique: an analysis of the first 180 cases. J Urol. 2001;166(6):2101-8.

15. Guillonneau B, Rozet F, Cathelineau X, Lay F, Barret E, Doublet J-D, et al. Perioperative complications of laparoscopic radical prostatectomy: the Montsouris 3-year experience. J Urol. 2002;167(1):51-6.

16. Stolzenburg J-U, Ho KMT, Do M, Rabenalt R, Dorschner W, Truss MC. Impact of previous surgery on endoscopic extraperitoneal radical prostatectomy. Urology. 2005;65(2):325-31. doi: https://doi.org/10.1016/j.urology.2004.09.026

17. Teber D, Erdogru T, Zukosky D, Frede T, Rassweiler J. Prosthetic mesh hernioplasty during laparoscopic radical prostatectomy. Urology. 2005;65(6):1173-8. doi: https://doi. org/10.1016/j.urology.2004.12.063

18. Chang CM, Moon D, Gianduzzo TR, Eden CG. The impact of prostate size in laparoscopic radical prostatectomy. Eur Urol. 2005;48(2):285-90. doi: https://doi. org/10.1016/j.eururo.2005.04.029

19. Massouh S, Aliaga A. Prostatectomía radical laparoscópica asistida por robot con preservación de la fascia endopélvica y complejo venoso dorsal. Revista Chilena de Urología. 2020

20. Tasci AI, Simsek A, Torer BD, Sokmen D, Sahin S, Tugcu V. Prostatectomía radical asistida por robot con conservación de nervios, intrafascial, con conservación de fascia y anastomosis vesicouretral anatómica: Técnica. Archivos españoles de urología. 2014;67(9):731-9 